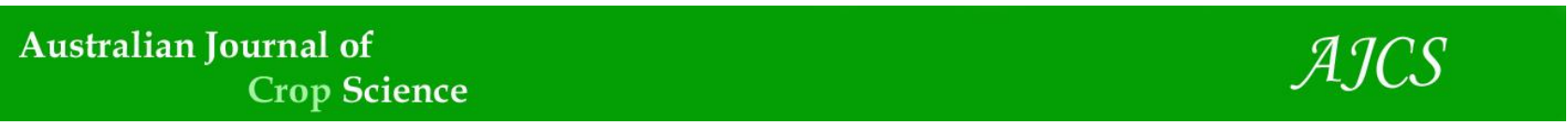

AJCS 15(06):821-826 (2021)

ISSN:1835-2707

doi: 10.21475/ajcs.21.15.06.p2857

\title{
High dynamic dilutions and genetic variability to phytosanitary management and yield of beans (Phaseolus vulgaris L)
}

\author{
Cezário Ferreira dos Santos Junior ${ }^{1}$, Claudio Córdoba Correoso ${ }^{1}$, Marcos Copacheski ${ }^{1}$, Pedro Boff ${ }^{1}$, Mari \\ Inês Carissimi Boff ${ }^{1}$
}

${ }^{1}$ Universidade do Estado de Santa Catarina, Lages, SC, Brasil
${ }^{2}$ Empresa de Pesquisa Agropecuária e Extensão Rural de Santa Catarina, Lages, Santa Catarina, Brasil

*Corresponding authors: ctc1182@gmail.com

\begin{abstract}
The substitution of landrace populations of beans (Phaseolus vulgaris L.) by commercial cultivars provided genetic uniformity and loss of rusticity. It makes the bean plants more vulnerable to pests, increasing the use of pesticides. The objective of this work was to evaluate the productivity and health of beans landraces compared to commercial cultivars, reducing the effect of high dynamic dilutions. The evaluated traits were grain yield $\left(\mathrm{kg} \mathrm{ha}^{-1}\right)$, thousand grain weight $(\mathrm{g})$, and occurrence of anthracnose (Colletotrichum lindemuthianum) and bacteriosis (Xanthomonas sp.). Evaluation of high dynamic dilutions was also done in addition to the previous variables, was evaluated number of pods per plant and pods with the presence of anthracnose. The analysis of the data did not show any differences in the productivity and disease rate between the landraces and the commercial cultivars of beans. The high dynamic dilutions do not show any conclusive results in terms of productivity. However, all treatments were superior in phytosanitary management compared to control.
\end{abstract}

Keywords: disease, homeopathy, productivity, resistance.

Abbreviations: DAP_days after planting; IUDPC_area index under the disease progress curve; DAE_days after emergency; CH_hahnemannian centesimal dynamization order; CV (\%)_coefficient of variation; kg ha-1 _kuilogram per hectare; g_ Grams.

\section{Introduction}

The Phaseolus vulgaris L. represent important factor of food and nutritional security, either in the acquisition by the lowincome population or in the self-support of farmers. In the Brazilian scenario, it stands out economically for family farming, in which landraces beans are mantained and traditionally used for subsequent crops (Michels et al., 2014). On the other hand, the introduction of transgenic technology has added the same issue into the agriculture as the use of pesticides. This makes a double problem, (a) dependence of the farmer to big corporations and (b) environmental liabilities of waste left by the pesticides and fertilizers with high solubility. Both, pesticides and seeds are available only in single type of cross-selling (Friedrich et al., 2017). Socio-environmental impacts of the use the seeds from market that are gradually changing elite hybrids/cultivars with genetic modified organismis/ transgenic are reported worldwide (Almeida et al., 2017). The abandonment of cultivation of own seeds by farmers influence popular knowledge. This has replaced the traditional culinary by fast-foods, resulting in food and nutritional insecurity. The transnational companies qualify landraces seeds as primitive. This is a strategy to weaken the local genetic resource and to encourage the consumption of hybrid and transgenic seeds (Carvalho and Bieger, 2016). On the other hand, family farming, with the predominant use of non-commodity crops, has been resisting the widespread and privatized trade of transgenic and offering resistance and maintaining the autonomy of the rural family (Magdaleno-Hernández et al., 2016). Bean landraces stand out for demonstrating their phenotype variability with adaptability to the ecological diversity of climate and soil. The phenotype stability is high in autogamous plants due to their conservative reproduction but with a bit inter-cross polinization that allow natural selection according to local environment conditions (Baldissera et al. 2014). Although, the populations of landraces beans do not always follow standardized descriptors and often do not meet the rigid and excluding certification regulators, they have extraordinary genetic, physical, physiological and sanitary attributes, which provides plasticity to be cultivated in different environments (Michels et al., 2014).

The management of agrobiodiversity under agroecological principles is considered a strategic for the perpetuation of the cultivated species in agroecosystems. The on-farm conservation of landraces is presented as one of the selection mechanisms to keep them more adapted to the local environmental conditions (Anunda et al., 2019). In another hand, farmers are losing their interests on landrace 
populations/varieties. These land varieties are widespread and have potential of elite productive attributes, without taking into account the conditions of soil-climate and the reduction in the plasticity of the selected varieties (Parra Filho et al. 2018). Therefore, identification and validation of efficiency by official agencies is essential to ensure the acceptance and strength of technologies for farmers, promoting the union between traditional knowledge and modern science.

Bean production systems, even with the use of landrace populations, may be sensitive to infestations of pests and diseases due to variations in soil fertility and climatic oscillations (Pereira et al., 2017). This induces the farmer to increase use of pesticides, even when they are under criticism of society for the problems caused to health and environment (Folgado, 2014). The restoration of the productive potential of neglected local bean genotypes can be aided by ecological management practices, such as nonresidual therapies (Capra et al. 2014). The high dynamized dilutions are such source of technology that can activate the resistance system of plants and improve the productive performance of plant crops, without having toxic residual effects on the environment and consumers, thus being a different alternative to the industrialized use of pesticides (Oliveira et al., 2014). Preparation of high dynamic dilutions has been proposed in the Homeopathy science. It acts to restore the vital energy of the living organism, allowing plant homeostasis and facilitates the expression of rusticity and tolerance to pests and diseases (Carneiro and Teixeira, 2018).

The objective of this work was to evaluate the production of landraces bean (Phaseolus vulgaris L.) used by family farmers, compared to commercial cultivars, and effect of high dynamic dilutions in phytosanitary management and productivity under field conditions.

\section{Results}

\section{Productive and phytosanitary aspects of landrace beans} and commercial cultivars

We verified a significant interaction between local cultivars for productivity $(p=0.0015)$ and thousand grain weight $(p<0.0001)$, which influenced the productive performance of the varieties studied differently between municipalities. The thousand grain weight in Vermelho and Carioca 2 beans were significantly higher than the commercial cultivars Predileto and Uirapuru in all municipalities. In addition, Carioca 1 and landrace Rosa bean populations in Lages, and Carioca 1 in São José de Cerrito differed from commercial cultivars (Table 1 ).

The highest values of yield in São José do Cerrito were observed for the landrace populations Preto $2(2.610 \mathrm{~kg}$ ha1), Tibagi (2.237 kg ha-1) and Preto $1\left(2.156 \mathrm{~kg} \mathrm{ha}^{-1}\right)$, which did not differ from the commercial cultivar Predileto (2.835 $\mathrm{kg} \mathrm{ha-1}$ ) and Uirapuru (2.579 $\left.\mathrm{kg} \mathrm{ha}^{-1}\right)$. The landrace population Preto 2 (1.838 $\mathrm{kg} \mathrm{ha}^{-1}$ ) in Anita Garibaldi presented a higher average than the commercial cultivars Uirapuru (1.621 kg ha-1) and Predileto (1.330 kg ha-1) (Table 1).

Similarly, there was difference between localities and incidence anthracnose $(p=0.0003)$ and bacteriosis $(p=$ 0.0115). In São José de Cerrito, the incidence of bacteriosis for the landrace population Carioca 2 (1.098) had the lowest average incidence than the Predileto (1.110) and Uirapuru
(1.682) cultivars. In Anita Garibaldi, populations such as Preto 2 (905), Rosa (1.025), Carioca 1 (1.212) and Preto 1 (1.229) obtained lower averages and did not differ statistically from the Predileto (1.268) and Uirapuru (1.334) cultivars, except the Capixaba population in Anita Garibaldi, which obtained a higher incidence of bacteriosis (Table 2).

\section{Yield and phytosanitary response to application of high dynamized dilutions}

In Lages, the yield presented significant differences when compared to the control. However, Silicea terra provided the highest absolute value, but without presenting statistical difference with the other high dynamized dilutions. In Campos Novos, Phosphorus had the highest absolute values of pod number per plant, differing significantly from the control and other treatments. Regarding the thousand grain weigh, there were significant differences in homeopathic preparations in relation to the control for the two locations of the experiment, being higher in Campos Novos and lower in Lages compared to other treatments (Table 3). Control differed from treatments with highest value at the number of pods with anthracnose, and area index under the disease progress curve (IUDPC) in anthracnose and bacteriosis in Campo Novos end Lages (Table 3, 4).

\section{Discussion}

According to Alves et al. (2018), the differentiated response of production of landrace populations to crop environments can occur due to phenotype differences, but with intense interaction of soil conditions, water availability and microclimates, which vary with planting and cultivation seasons. Soares Júnior et al. (2015), studied genotypes of red landrace beans and showed differences. Safira beans have larger dimensions and lighter color, Vermelho Rajado beans and Bolinha Vermelha higher protein content, Jalo Roxo beans higher ash and ether extract and Vermelho Rajado higher fiber content, demonstrating the genetic variation.

EMBRAPA (2016), landrace beans (Vigna unguiculata (L.) Walp.) have a higher production than commercial beans, attributing this result to the great biodiversity of landrace species and the selection made by farmers. According to Bertoldo et al. (2014), bean genotypes have great diversity of attributes that can be used in genetic improvement for changes in plant height, height of insertion of the first pod, extending the life cycle and grain yield.

Due to the great variability of cultivars, several commercial groups of beans such as cariocas, butter, purple and blacks stand out. Kappes et al. (2008), showed that the cultivar BRS Pitanga purple group had the highest number of pods/plant. The cultivars BRS Jalo and BRS Radiante of the butter group had the largest mass of 100 seeds. The BRS Valente of the black group and BRS Pitanga group purple were the most productive. Even the carioca and black groups are more consumed in Brazil. The Roxo, Vermelho and Rosa groups are also grains being used in regional cuisine. The bean has a great genetic variation. Gouveia et al. (2014), revealed 52 accessions of beans distributed throughout the island of Madeira, in Portugal. Fioreze et al. (2018), reported that the local varieties of grains in the red group are resistant or moderately resistant to anthracnose Colletotrichum lindemuthianum (Sacc. \& Magnus) and adapt to local environmental conditions. 
Table 1. Grain yield and thousand grain weight in the municipalities of Lages, São José de Cerrito and Anita Garibaldi. 2013/2014 crop cycle, SC.

\begin{tabular}{|c|c|c|c|c|c|c|c|}
\hline Common name* & Group & \multicolumn{4}{|c|}{ Grain yield $\left(\mathrm{kg} \mathrm{ha}^{-1}\right)$} & \multicolumn{2}{|c|}{ Thousand grain weight (g) } \\
\hline Preto 1 & Preto & $1217^{\mathrm{ns}}$ & $2156^{\mathrm{abc}}$ & $1487^{a b c}$ & $210^{c}$ & $216^{\text {def }}$ & $196^{\mathrm{cd}}$ \\
\hline Vermelho & Cores & 1526 & $1633^{b c}$ & $1493^{\mathrm{abc}}$ & $472^{\mathrm{a}}$ & $434^{a}$ & $435^{a}$ \\
\hline Rosa & Cores & 1293 & $1969^{\mathrm{abc}}$ & $709^{d e}$ & $272^{b}$ & $238^{\mathrm{cd}}$ & $188^{\text {cde }}$ \\
\hline Tibagi & Preto & 1147 & $2237^{a b c}$ & $889^{\text {bcde }}$ & $209^{c}$ & $207^{\mathrm{ef}}$ & 169 de \\
\hline Uirapuru & Preto & 1268 & $2579^{a b}$ & $1621^{\mathrm{ab}}$ & $199^{c}$ & $208^{\mathrm{ef}}$ & $184^{\text {de }}$ \\
\hline Carioca 1 & Carioca & 1122 & $1408^{c}$ & $438^{e}$ & $261^{b}$ & $262^{b c}$ & $219^{b c}$ \\
\hline Predileto & Preto & 935 & $2835^{a}$ & $1330^{\mathrm{abcd}}$ & $214^{c}$ & $214^{\text {de }}$ & $189^{\text {cde }}$ \\
\hline CV (\%) & & 37.96 & 19.95 & 26.38 & 4.7 & 4.36 & 5.92 \\
\hline
\end{tabular}

Averages followed by the same letter, in the column, do not differ from each other by the Tukey test at $5 \%$ significance; ns = Not significant. ${ }^{*}$ Popular name: regional name provided by the farmer himself.

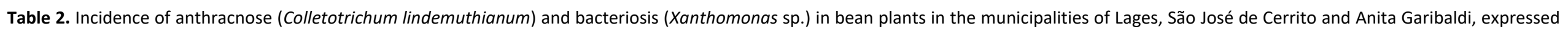
by the area index under the disease progress curve (IUDPC). 2013/2014 harvest, SC.

\begin{tabular}{|c|c|c|c|c|c|c|c|}
\hline \multirow[t]{2}{*}{ Common name* } & \multirow[t]{2}{*}{ Group } & \multicolumn{4}{|c|}{ Antracnosis } & \multicolumn{2}{|l|}{ Bacteriosis } \\
\hline & & Lages & São José de Cerrito & Anita Garibaldi & Lages & São José de Cerrito & Anita Garibald \\
\hline Preto 1 & Pretos & $914^{\mathrm{ab}}$ & $278^{a b}$ & $861^{\mathrm{ab}}$ & $981^{\text {ns }}$ & $1560^{\mathrm{ab}}$ & $1229 b c$ \\
\hline Vermelho & Cores & $16^{\mathrm{b}}$ & $35^{b}$ & $230^{c}$ & 916 & $2885^{\mathrm{ab}}$ & $2269^{a b}$ \\
\hline Rosa & Cores & $1339^{a b}$ & $298^{\mathrm{ab}}$ & $4402^{\mathrm{ab}}$ & 2710 & $2225^{a b}$ & $1025^{c}$ \\
\hline Capixaba & Pretos & $881^{a b}$ & $196^{b}$ & $5154^{a b}$ & 1771 & $3611^{a}$ & $2971^{a}$ \\
\hline Tibagi & Pretos & $1212^{\mathrm{ab}}$ & $630^{\mathrm{ab}}$ & $4848^{a b}$ & 1252 & $2045^{a b}$ & $1431^{b c}$ \\
\hline Uirapuru & Pretos & $86^{b}$ & $363^{a b}$ & $3531^{b c}$ & 607 & $1682^{\mathrm{ab}}$ & $1334^{b c}$ \\
\hline Carioca 1 & Carioca & $2449^{a}$ & $1195^{\mathrm{a}}$ & $6725^{a}$ & 907 & $1201^{b}$ & $1212^{c}$ \\
\hline Carioca 2 & Carioca & $515^{b}$ & $181^{\mathrm{b}}$ & $2692^{\mathrm{bc}}$ & 236 & $1098^{b}$ & $1382^{\mathrm{bc}}$ \\
\hline Preto 2 & Pretos & $709^{a b}$ & $228^{\mathrm{ab}}$ & $4302^{\mathrm{ab}}$ & 496 & $2518^{a b}$ & $905^{c}$ \\
\hline Predileto & Pretos & $1138^{\mathrm{ab}}$ & $478^{\mathrm{ab}}$ & $3605^{b c}$ & 1270 & $1110^{b}$ & $1268^{b c}$ \\
\hline CV (\%) & & 81.84 & 104.48 & 25.26 & 70.2 & 42.17 & 28.86 \\
\hline
\end{tabular}

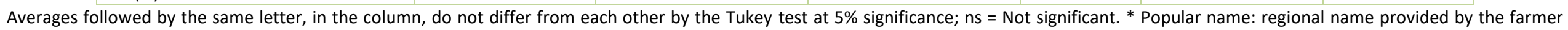
himself. 


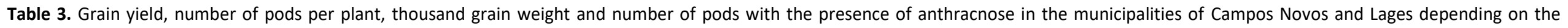
preparations. 2013/2014 harvest, SC

\begin{tabular}{|c|c|c|c|c|c|c|c|c|}
\hline \multirow[t]{2}{*}{ Preparations } & \multicolumn{2}{|l|}{$\begin{array}{l}\text { Grain yield } \\
\left(\mathrm{kg} \mathrm{ha}^{-1}\right)\end{array}$} & \multicolumn{2}{|l|}{$\begin{array}{l}\text { Pods/Plant } \\
\text { (No.) }\end{array}$} & \multicolumn{2}{|c|}{ Thousand grain weight (g) } & \multicolumn{2}{|c|}{ Pods with anthracnosis (No.) } \\
\hline & Campos Novos & Lages & Campos Novos & Lages & Campos Novos & Lages & Campos Novos & Lages \\
\hline Control & $1580.78^{a}$ & $1136.06^{b}$ & $17.73^{b}$ & $14.28^{\mathrm{ns}}$ & $51.08^{a}$ & $171.37^{b}$ & $51.08^{a}$ & $21.33^{\mathrm{a}}$ \\
\hline $\mathrm{T} 1$ & $1941.93^{\mathrm{a}}$ & $1580.63^{\mathrm{a}}$ & $20.11^{\mathrm{ab}}$ & 14.58 & $21.67^{b}$ & $212.39^{a}$ & $21.67^{b}$ & $1.67^{b}$ \\
\hline $\mathrm{T} 2$ & $1858.10^{\mathrm{a}}$ & $1482.89^{a}$ & $21.88^{a}$ & 14.60 & $17.17^{b}$ & $214.97^{a}$ & $17.17^{b}$ & $1.92^{b}$ \\
\hline T3 & $1950.82^{a}$ & $1698.43^{a}$ & $20.76^{a b}$ & 15.23 & $5.33^{b}$ & $230.69^{a}$ & $5.33^{b}$ & $1.25^{b}$ \\
\hline CV (\%) & 21.10 & 18.93 & 18.40 & 29.17 & 53.30 & 22.52 & 53.30 & 83.24 \\
\hline
\end{tabular}

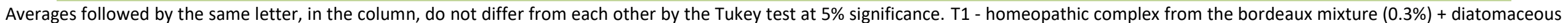
earth (0.5\%); T2 - homeopathic preparation of Phosphorus; T3 - homeopathic preparations of Silicea terra.

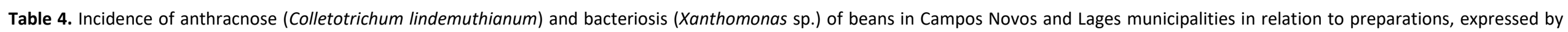
the area index under the disease progress curve (IUDPC). 2013/2014 harvest, SC

\begin{tabular}{|c|c|c|c|c|}
\hline \multirow{3}{*}{ Preparations } & \multicolumn{4}{|c|}{ Area index under the disease progress curve (IUDPC) } \\
\hline & \multicolumn{2}{|l|}{ Bacteriosis } & \multicolumn{2}{|l|}{ Antracnosis } \\
\hline & Campos Novos & Lages & Campos Novos & Lages \\
\hline Control & $3393^{a}$ & $3001^{a}$ & $1090^{\mathrm{a}}$ & $1279^{a}$ \\
\hline T1 & $2049^{b}$ & $2050^{\mathrm{b}}$ & $388^{\mathrm{b}}$ & $175^{b}$ \\
\hline $\mathrm{T} 2$ & $2029^{b}$ & $2113^{b}$ & $315^{b}$ & $139^{b}$ \\
\hline T3 & $1955^{b}$ & $2057^{b}$ & $335^{b}$ & $63^{b}$ \\
\hline$p$-value of $F$ & $<0.0001$ & $<0.0001$ & 0.0019 & $<0.0001$ \\
\hline
\end{tabular}

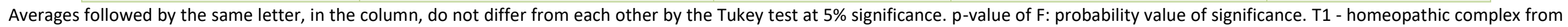
the bordeaux mixture $(0.3 \%)+$ diatomaceous earth $(0.5 \%)$; T2 - homeopathic preparation of Phosphorus; T3 - homeopathic preparations of Silicea terra. 
This directly affects productive performance. The result of the incidence of anthracnose demonstrates that landrace beans did not differ statistically from Predileto and Uirapuru cultivars between the study areas. The landrace red population presented lower absolute average values and Carioca 1 averaged higher than anthracnose attacks in all municipalities.

Miranda et al. (2015) reported that variation in the pathogenicity of the bacteria interferes with the development of varieties with vertical or specific resistance. Therefore, identification of cultivars resistant to a wide range of pathogenicity of Xanthomonas sp. is very important. The pathogenic variation of this bacterium hinders the development of resistant bean cultivars in all environments that can be cultivated.

The different values between the municipalities may be related to the adaptation of the varieties to the premises. The attributes of disease resistance and productivity are explained by the manifestations of genetic characteristics in certain environments (Anunda et al., 2019). Studies on cultivation of soybeans show that Phosphorus and Silicea increase the production and strengthen the defense of plant and improve phosphorus absorption, mainly in deficit soils (Riguetto et al. 2016).

The use of high dynamic dilutions allows the induction of resistance in organisms, through the production of beneficial substances in the fight against diseases in plants. The results found by Oliveira et al. (2018), using the high dynamic dilutions of $C$. citriodora, $C$. carbonica, Silicea and Sulfur showed the capacity to induce defense enzymes with increased peroxidase, catalase, chitinase, $\beta$-1.3-glucanase and phytoalexin activity.

Rissato et al. (2018) analyed the antifungal activity of high dynamized dilutions on white mold (Sclerotinia sclerotiorum) of beans (Phaseolus vulgaris). They observed that Phosphorus $12 \mathrm{CH}$, Phosphorus $48 \mathrm{CH}$, Calcarea carbonica $12 \mathrm{CH}$ and Calcarea carbonica $48 \mathrm{CH}$ cause delays of up to $83 \%$ on disease progression and decrease by up to $90 \%$ on the number of dead plants. Phosphorus $12 \mathrm{CH}$, Phosphorus $48 \mathrm{CH}$ and Calcarea carbonica $48 \mathrm{CH}$ also postponed mycelial growth. Toledo et al. (2015) managed to keep the population of Alternaria solani below the control level in tomatoes using high dynamic dilutions of Propolis, Sulfur and Ferrum sulphuricum (Solanum lycopersicum L.).

\section{Materials and Methods}

\section{Comparisons of landrace populations and commercial bean cultivars}

The study was conducted in three municipalities during the 2013/2014 crop cycle: (a) Experimental station of the Agricultural Research and Rural Extension Service of Santa Catarina-EPAGRI, in Lages, and two family rural properties in the municipalities of (b) Anita Garibaldi and (c) São José de Cerrito, all located in the Southern Plateau of Santa Catarina State, Brazil. The cultivation areas received organic fertilizer at a rate of five tons per hectare, three months before planting. There were no controls on diseases and pests, aiming to make possible estimation of the natural reaction of genotypes to phytosanitary problems.

The experiments were conducted with local populations of landrace beans, called Capixaba, Carioca 1, Carioca 2, Preto 1, Preto 2, Rosa, Tibagi and Vermelho from family farmers and two commercial cultivars Uirapuru and Predileto. The experimental design was randomized blocks with four repetitions. The plots consisted of four meters in length and four lines with $50 \mathrm{~cm}$ spacing. The final density, after thinning, presented an amount of 13 to 15 plants per linear meter. The total area per plot was eight square meters.

The field evaluations included estimating the incidence of diseases that occurred during the crop cycle. It started during the vegetative state and followed until the ripening of the pods at 28, 56, 70, 87 and 100 days after planting (DAP) in Lages; at 21, 60, 71, 84 and 103 DAP in Anita Garibaldi and at 28, 57, 78, 94 and 106 DAP in São José do Cerrito. We estimated the incidence of diseases by the proportion of plants with symptoms of bacteriosis (Xanthomonas sp.) and anthracnose (Colletotrichum lindemuthianum). We randomly chose the plants to be evaluated in the two central rows of each plot. The incidence of anthracnose and bacteriosis were expressed by the area index under the disease progress curve (IUDPC). The formula was used: AACPD $=\Sigma$ $((Y i+Y i+1) / 2)(t i+1-t i)$, where $Y$ represents the intensity (incidence and severity) of the disease, $t$ the time and $i$ the number of assessments over time, according to Campbell and Madden (1990). The grains were harvested and grain yield $\left(\mathrm{kg} \mathrm{ha}^{-1}\right)$ and thousand grain weight $(\mathrm{g})$ were evaluated.

\section{High dynamized dilutions applied to bean crops}

We conducted the work in the Experimental Stations in Lages and Campos Novos of the Agricultural Research and Rural Extension Company of Santa Catarina-EPAGRI during the 2013/2014 harvest (the two rural properties were not included in this experiment). We adopted cultivation techniques for organic production systems, with five manual weeding for the control of spontaneous plants and thinning of plants at 15 days after emergency (DAE), resulting in final densities of 12 plants per linear meter. We set the experimental design in randomized blocks with four repetitions. The experimental plots counted four lines of five meters, spaced $0.5 \mathrm{~m}$. We used Preto bean cultivars (Phaseolus sp.) and three preparations under high dynamized dilutions: T1 - homeopathic complex from the bordeaux mixture $(0.3 \%)+$ diatomaceous earth $(0.5 \%) ; \mathrm{T} 2$ homeopathic preparation of Phosphorus; T3 - homeopathic preparations of Silicea terra, and control without application. We purchased Phosphorus and Silicea preparations as matrices in the $5 \mathrm{CH}$ (hahnemannian centesimal dynamization order) potency from specialized pharmacy in Lages, SC. We raised preparations to the potency of $30 \mathrm{CH}$, at the EPAGRI Homeopathy and Plant Health Laboratory in Lages, according to the methodology described in the Brazilian Homeopathic Pharmacopoeia (Brazil 2011).

The applications of preparations were weekly from emergence of the first true leaves, about 14 days after the emergency (DAE), until the maturation phase of the pods at 90 DAE. The dosage of preparations was $10 \mathrm{ml} \mathrm{L}^{-1}$. We performed the anthracnose and bacteriosis incidence evaluations by the area index under the disease progress curve (IUDPC) during the vegetative cycle. We carried out five non-destructive evaluations during the crop cycle at 31 , $48,62,71$ and 78 days after sowing (DAP), in Lages, and 49, $55,77,85$ and 95 DAP in Campos Novos. We estimated the incidence by the proportion of plants with symptoms of anthracnose and bacteriosis in relation to the ten central plants of each plot. The harvest was made at 98 and 105 DAP, in Lages and Campos Novos, respectively. We measured the grain yield $\left(\mathrm{kg} \mathrm{ha}^{-1}\right)$, number of pods per plant and thousand grain weight $(\mathrm{g})$. During the harvest, we 
evaluated the number of pods with the presence of anthracnose.

\section{Data analysis}

We subjected the data to an analysis of variance and the averages were compared by the Tukey's test $(5 \%)$. We adjusted the data that did not meet the assumption of variance analysis by the Box-Cox methodology, aiming to reduce the variability and normalize the errors (Venables and Ripley 2002). We performed the statistical analysis through the statistical program $R$, version 3.0.3 ( $R$ Core Team 2014).

\section{Conclusion}

Landrace beans did not differ in yield compared to commercial cultivars. However, the Red and Carioca population had a weight of one thousand grains (g) higher in the municipalities of São José de Cerrito and Anita Garibaldi. Regarding the phytosanitary criteria, landrace population did not show differences from commercial cultivars.

Bean populations undergoing preparations under high dynamized dilutions did not show conclusive values of being superior in production relative to the control. However, in terms of phytosanitary criterion, cultivars evaluated with preparations were significantly higher than the control.

\section{Acknowledgements}

This research was supported by FAPESC (Rede Guarani Serra Geral, conv. FAPESC2015TR1067). The first author is thankful to PROMOP/CAV UDESC for granting PhD scholarship. To CNPq for an award for excellence in research (process $\mathrm{n}$. 304018/2015 and 307376/2017-6).

\section{References}

Almeida VES, Friedrich K, Tygel AF, Melgarejo L, Carneiro FF (2017) Uso de sementes geneticamente modificadas e agrotóxicos no Brasil: cultivando perigos. Ciência \& Saúde Coletiva. 22(10): 33333339.

Alves CX, Gilberto Bevilaqua GAP, Schuch LOB, Antunes IF, Eberhardt PER (2018) Teor de macro e micronutrientes e potencial fisiológico de sementes em genótipos crioulo e melhorado de feijão. Colloquium Agrariae. 14(1): 79-91.

Anunda HN, Nyaboga EM, Amugune NO (2019) Genetic diversity of common bean (Phaseolus vulgaris L.) landraces from South Western Kenya for resistance to Pythium root rot disease. African Journal of Biotechnology. 18(15): 316-324.

Baldissera JNC, Valentini G, Coan MMDC, Guidolin AF, Coimbra JLM (2014) Fatores genéticos relacionados com a herança em populações de plantas autógamas. Revista de Ciências Agroveterinárias. 13(2): 181-189.

Bertoldo JG, Coimbra JLM, Guidolin AF, Andrade LRB, Nodari RO (2014) Agronomic potential of genebank landrace elite accessions for common bean genetic breeding. Scientia Agricola. 71(2): 120125.

BRASIL (1990) Farmacopeia Homeopática Brasileira, 3a. ed.

Campbell, C.L, Madden. L.V (1990) Introduction to plant disease epidemiology. New York: J. Wiley \& Sons. 532 p.

Capra RS, Gratão AS, Freitas GB, Leite MN (2014) Preparados homeopáticos e ambiente de cultivo na produção e rendimento de quercetina em carqueja [Baccharis trimera (Less) DC.]. Rev Bras PI Med.16(3): 566-573.

Carneiro SMTPG, Teixeira MZ (2018) Homeopatia e controle de doenças de plantas e seus patógenos. Sci Agrar Parana. 17(3): 250-262.
Carvalho MT, Bieger JT (2016) Abordagem crítica relacionada a alimentos transgênicos. R. bras. Tecnol. Agroindustr. 10(1): 19751990.

EMBRAPA (2016) Desempenho de Variedades Crioulas e Comerciais de Feijão-Macassar ou Feijão-Caupi no Agreste Paraibano. Comunicado Técnico.

Fioreze ACCL, Grigolo S, Guginski, Piva CA, Sartori L (2018) Common bean landraces as potential sources of resistance to anthracnose. Pesq Agropec Trop. 48(2): 126-133.

Folgado RAC (2014) Agrotóxicos: um problema invisibilizado. Caderno de Estudos Para as Bases I. Movimento dos Pequenos Agricultores-MPA-CLOC. Via Campesina. 32p. Brasília, DF.

Friedrich K, Tygel AF, Melgarejo L, Carneiro FF (2017) Uso de sementes geneticamente modificadas e agrotóxicos no Brasil: cultivando perigos. Ciência \& Saúde Coletiva. 22(10): 3333-3339.

Gouveia CSS, Freitas G, Brito JH, Slaski JJ, Carvalho MAAP (2014) Nutritional and mineral variability in 52 accessions of common bean varieties (Phaseolus vulgaris L.) from Madeira Island. Agricultural Sciences. 5(4): 317-329.

Kappes C, Wruck FJ, Carvalho MA, Yamashita OM (2008) Componentes produtivos de cultivares de feijão comum em cultivo safrinha. Documentos IAC. Genética e Melhoramento. Campinas.

Magdaleno-Hernández E, Mejía-Contreras A, Martínez-Saldaña T, Jiménez-Velazquez MA, Sanchez-Escudero J, García-Cué, JL (2016) Selección tradicional de semilla de maíz criollo. Agricultura, sociedad y desarrollo. 13(3): 437-447.

Michels AF, Souza CA, Coelho CMM, Zilio M (2014) Qualidade fisiológica de sementes de feijão crioulo produzidas no oeste e planalto catarinense. Revista Ciência Agronômica. 45(3): 620-632.

Miranda OR, Álvarez BF, Pérez RO, Lorigado SM, Piedra AL (2015) Answer to common bacterial blight (Xanthomonas axonopodis p.v phaseoli) in the commercial cultivars of common bean of Cuba, under field conditions. Affectation of the yields for effect of the inoculation. Cultivos Tropicales. 36(2): 92-99.

Oliveira JS, Maia AJ, Schwan-Estrada KRF, Bonato CM, Solange GC Pizza MT, Picoli MH (2014) Activation of biochemical defense mechanisms in bean plants for homeopathic preparations. African Journal of Agricultural Research. 9(11): 971-981.

Parra Filho ACM, Norder LAC, Jovchelevich P, Kinjo SA (2018) Convencionalização na Produção de Sementes na Agricultura Orgânica Brasileira. Rev Econ Sociol Rural. 56(4): 565-582.

Pereira VC, López PA, Dal FK (2017) A conservação das variedades crioulas para a soberania alimentar de agricultores: análise preliminar de contextos e casos no Brasil e no México. HOLOS. 4(33): 37-55.

R Core Team (2014) R: A language and environment for statistical computing. R. Foundation for Statistical Computing, Vienna, Austria. Disponível em: http://www.R-project.org/. Acesso em: 03 jan. 2015.

Riguetto CS, Souza Júnior, JB, Mouro GF, Macena AM, Diniz E.R (2016) Efeito de preparados homeopáticos na produtividade da cultura da soja (Glycine max L.). Cadernos de Agroecologia. 11(2).

Rissato BB, Stangarlin, JR, dildey, Omari DF, Silva CR, GonçalvesTrevisoli, E V, Coltro-Roncato S, Webler TFB, Kuhn OJ, Alves Neto AJ (2018) Fungitoxicity activity of Phosphorus and Calcarea carbonica against Sclerotinia sclerotiorum and control of white mold in common bean (Phaseolus vulgaris) with extremely diluted aqueous solutions. Australian Journal Of Crop Science. 12(4): 546551.

Soares Júnior MS, Caliari M, Becker FS, Souza ERB, Vera R(2015) Propriedades físicas e químicas de grãos de feijões crioulos vermelhos. Revista Caatinga. 28(1): 263-269.

Toledo MV, Stangarlin JR, Carlos Bonato CM (2015) Controle da pinta preta e efeito sobre variáveis de crescimento em tomateiro por preparados homeopáticos. Summa Phytopathol. Botucatu, 41(2): 126-132.

Venables WN, Ripley BD (2002) Modern Applied Statistics with S. Fourth Edition. Springer, New York. ISBN 0-387-95457-0. 